\title{
Changes in Bio-Chemical Properties of Whole and Sliced Fruits of Frozen Aonla cv. "Gujarat Aonla-1" Treated with Anti Darkening Chemical and Different Packaging
}

\author{
V.K. Patel ${ }^{*}$, B.H. Panchal, M.C. Joshi and R.A. Khimani \\ Department of Horticulture, B.A. College of Agriculture, A.A.U, Anand, Gujarat, India \\ *Corresponding author
}

\begin{tabular}{|l|}
\hline Ke y w o r d s \\
Aonla, Slices, \\
$\begin{array}{l}\text { Frozen, Aluminium } \\
\text { foil. }\end{array}$ \\
\hline Article Info \\
\hline $\begin{array}{l}\text { Accepted: } \\
\text { 04 September } 2017 \\
\text { Available Online: } \\
\text { 10 October } 2017\end{array}$ \\
\hline
\end{tabular}

\section{Introduction}

Aonla or Indian gooseberry (Emblica officinalis Gaertn), a versatile tree is adaptable in diverse soil and climatic conditions. The fruits have high nutritive and therapeutic values. It is used in more than fifty products and ayurvedic formulations among which, aonla pulp, juice, squash, RTS beverage, jam, candy, powder, etc. are more popular. Storage of fresh fruits as well as its products is essential to capture the emerging consumer market. Inappropriate packaging and handling damage the fruits and facilitate development of many post-harvest disorders or diseases. The present information on postharvest storage and packaging is not sufficient to extend the shelf life of aonla. Therefore, there is an urgent need to develop technologies for packing of fresh fruits to 
minimize the losses. Aonla fruits develop darkening if their cut surfaces exposed to air. Citric acid or ascorbic acid can be used to prevent darkening and flavor loss of aonla fruits. It not only preserves natural colour and flavor of fruits, but adds nutritive value as well. Quick freezing is one of the easiest and least time-consuming ways for storage of fresh fruits. Extreme cold in freezing retards growth of microorganisms and slows down changes that affect quality or cause spoilage in fresh fruits. Little information is available on the use of packaging for freezing of fruits. Therefore, an investigation was taken to study anti-darkening treatments and packaging materials on whole and sliced frozen fruits of aonla cv. Gujarat Aonla-1.

\section{Materials and Methods}

The present investigation was carried out at Department of Horticulture, B.A. College of Agriculture, Anand Agricultural University, Anand, during the year 2005-2006. The fruits were selected from a single tree for uniformity in fruits. The treatments include fruit preparation types (F1: whole fruit, $\mathrm{F} 2$ : sliced fruit), preservative treatments $(\mathrm{C} 1: 1 \%$ ascorbic acid, C2: $1 \%$ citric acid, C3: control (water)) and three packing materials (P1: aluminum foil bag, P2: 200 gauge polyethylene bag, P3: inner side laminated paper box. The treated fruits were quick frozen at $-30^{\circ} \mathrm{C}$ for 12 hours and stored at$18^{\circ} \mathrm{C}$ in cold storage in two lots. Initially, fresh fruits (T1) were analyzed for physicochemical parameters. First lot was taken out from cold storage after four months (T2) while the second lot was taken out after eight months (T3) and analyzed for physicochemical changes. Total soluble solids were determine with the help of hand refractometer. Fruit firmness was determine by using penetrometer, moisture was determine by oven dry method while titrable acidity, ascorbic acid and tanin ware determined as per standard procedures of
Rangana (1979). The trial was laid out in a Complete Randomized Block Design with factorial concept. The data were subjected to statistical analysis.

\section{Results and Discussion}

\section{Ascorbic Acid (Vitamin C) (mg/100g)}

Data shown in table 1 indicated that whole fruits $\left(F_{1}\right)$ contained significantly higher ascorbic acid content than sliced fruits $\left(\mathrm{F}_{2}\right)$. This may be due to sliced fruits had higher rate of respiration, oxidation and other physico-chemical activities because of open surface area. Among the different packing treatments, aonla fruits packed in aluminum foil bag $\left(\mathrm{P}_{1}\right)$ had significantly higher vitamin $\mathrm{C}$ than fruits stored in polyethylene bag $\left(\mathrm{P}_{2}\right)$ and laminated paper box $\left(\mathrm{P}_{3}\right)$. This might be due to modified micro environment in this packaging in terms of high $\mathrm{CO}_{2}$ and low $\mathrm{O}_{2}$ concentration which ultimately resulted in reduced respiration and oxidation of fruits (Thakur and Arya, 1988). From storage durations, fresh fruits recorded significantly higher vitamin $\mathrm{C}$ than fruits stored for four and eight months. Reduction in vitamin $\mathrm{C}$ content during storage periods could be attributed to the conversion of L-ascorbic acid into dihydro-ascorbic acid in the presence of ascorbinase enzyme (Mapson, 1970). These results are in agreement with findings of Singh et al., (1987), Nath et al., (1992) and Patra and Sadhu (1992).

Interaction of $\mathrm{F} \times \mathrm{T}$ had significant effect on vitamin $\mathrm{C}$ content of frozen aonla (Table 2). The highest vitamin $\mathrm{C}$ content was noted in treatment combination of $\mathrm{F}_{1} \mathrm{~T}_{1}$ (whole fruits at initial period) which is obvious because whole fruits had least enzymatic oxidation and respiration as compared to sliced fruits. Data also indicated that with increasing storage period up to eight months, the vitamin $\mathrm{C}$ content of aonla fruits decreased significantly. However, the rate of reduction 
was less in whole fruits as compared to sliced fruits. The $\mathrm{P} \times \mathrm{T}$ interaction was also significant for vitamin $\mathrm{C}$ content in which maximum was noted in treatment combination $\mathrm{P}_{1} \mathrm{~T}_{1}$ (fruits packed in aluminium foil bag at initial period) and it was at par with $\mathrm{P}_{2} \mathrm{~T}_{1}$ and $\mathrm{P}_{3} \mathrm{~T}_{1}$.

\section{Acidity (\%)}

Data on acidity content of frozen aonla fruits (Table 3) showed that whole fruits had significantly higher acidity as compared to sliced fruits during the storage period. This might possibly because of higher respiration loss of acids from sliced fruits. Among the storage durations, initially fruits had significantly higher acidity content than $T_{2}$ and $T_{3}$. The reduction of acidity during storage might be due to the utilization of acids in the respiratory processes. These results corroborate the findings of Bhullar et al., (1981); Singh et al., (1987) and Patra and Sadhu (1992). Interaction effect of F×T had significant influence on acidity content of frozen aonla (Table 4) where the treatment combination of $\mathrm{F}_{1} \mathrm{~T}_{1}$ i.e. whole fruits at initial period had significantly higher acidity and remained at par with $F_{2} T_{1}$ i.e. sliced fruits at initial period. The acidity was significantly decreased with increasing storage period, but the reduction was significantly less in whole fruits as compared to sliced fruits. This might be due to low rate of respiration in $\mathrm{F}_{1}$ (whole fruits) as compared to $\mathrm{F}_{2}$ (sliced fruits)

\section{Tannin $(g / 100 g)$}

Whole fruits recorded significantly higher tannin than $\mathrm{F}_{2}$ which might be due to more respiration from cut surface of slices and therefore utilization of more Tannic acid in these processes (Table 5). In case of packing materials the fruits packed in aluminium foil bag $\left(\mathrm{P}_{1}\right)$ had less respiration and therefore less tannic acid utilized. Due to this fruits packed in $\mathrm{P}_{1}$ recorded significantly higher amount of tannin. From storage durations $\mathrm{T}_{1}$ i.e. initially aonla fruits had significantly higher level of tannin. Increasing storage period from $T_{1}$ to $\mathrm{T}_{3}$ tannin content decreased significantly. This may be due to the fact that in fresh fruits tannin content was not much affected, but with increasing storage period tannic acid decreased gradually because of respiration.

The $\mathrm{F} \times \mathrm{T}$ and $\mathrm{P} \times \mathrm{T}$ interactions on tannin content of aonla were significant (Table 6). The whole fruits at initial period $\left(\mathrm{F}_{1} \mathrm{~T}_{1}\right)$ had maximum amount of tannin and it remained at par with sliced fruits at initial period $\left(\mathrm{F}_{2} \mathrm{~T}_{1}\right)$.With increasing storage period from $\mathrm{T}_{1}$ to $\mathrm{T}_{3}$ there was significant reduction in tannin content of aonla in both type of fruit preparations i.e. whole and sliced, but the reduction was significantly less in whole fruits as compared to slices. In $\mathrm{P} \times \mathrm{T}$ interaction, though the treatment combination of $\mathrm{P}_{1} \mathrm{~T}_{1}$ had significantly higher tannin content, there was not much difference in tannin content of aonla at initial period of storage but after four and eight months, there was significant reduction in tannin content in all the three packaging treatments. However, fruits packed in aluminum foil bag $\left(\mathrm{P}_{1}\right)$ showed significantly less reduction of tannin in aonla than $\mathrm{P}_{2}$ and $\mathrm{P}_{3}$ packing treatments. The interaction of $\mathrm{F} \times \mathrm{P} \times \mathrm{T}$ showed significant variation for tannin content in aonla fruits (Table 7). The maximum tannin content was observed in treatment combination of $\mathrm{F}_{1} \mathrm{P}_{1} \mathrm{~T}_{1}$ (whole fruits packed in aluminium foil bag at initial period) which was at par with $\mathrm{F}_{1} \mathrm{P}_{2} \mathrm{~T}_{1}$, $\mathrm{F}_{1} \mathrm{P}_{3} \mathrm{~T}_{1}, \mathrm{~F}_{2} \mathrm{P}_{1} \mathrm{~T}_{1}, \mathrm{~F}_{2} \mathrm{P}_{2} \mathrm{~T}_{1}$ and $\mathrm{F}_{2} \mathrm{P}_{3} \mathrm{~T}_{1}$. Initially fruits were fresh hence tannin content was not affected by type of fruit preparation as well as packaging. At later stages of storage tannin content was significantly higher in whole fruits packed in aluminium foil bag for four and eight months $\left(\mathrm{F}_{1} \mathrm{P}_{1} \mathrm{~T}_{2}\right.$ and $\left.\mathrm{F}_{1} \mathrm{P}_{1} \mathrm{~T}_{3}\right)$ as compared to the rest which might be due to less rate of respiration which kept utilization of tannic acid at lower level and helped to maintain more tannin during storage period. 
Table.1 Individual effect of F, P and T on ascorbic acid content of frozen aonla

\begin{tabular}{|c|c|c|c|c|c|c|}
\hline Treatments & 1 & 2 & 3 & CD at 5\% & S.Em. \pm & CV \% \\
\hline $\mathbf{F}$ & 785.88 & 759.01 & & 5.43 & 1.94 & \multirow{3}{*}{2.26} \\
\hline $\mathbf{P}$ & 779.44 & 772.76 & 765.14 & 6.65 & 2.37 & \\
\hline $\mathbf{T}$ & 960.37 & 727.00 & 629.97 & 6.65 & 2.37 & \\
\hline
\end{tabular}

Table.2 Interaction effects of $\mathrm{F} \times \mathrm{T}$ and $\mathrm{P} \times \mathrm{T}$ on ascorbic acid content of frozen aonla

\begin{tabular}{|c|c|c|c|c|c|}
\hline Treatments & $\mathbf{F}_{\mathbf{1}}$ & $\mathbf{F}_{\mathbf{2}}$ & $\mathbf{P}_{\mathbf{1}}$ & $\mathbf{P}_{\mathbf{2}}$ & $\mathbf{P}_{\mathbf{3}}$ \\
\hline $\mathbf{T}_{\mathbf{1}}$ & 961.64 & 959.10 & 960.19 & 959.99 & 960.92 \\
\hline $\mathbf{T}_{\mathbf{2}}$ & 748.24 & 705.76 & 737.56 & 726.39 & 717.04 \\
\hline $\mathbf{T}_{\mathbf{3}}$ & 647.76 & 612.18 & 640.55 & 631.90 & 617.47 \\
\hline CD at 5\% & \multicolumn{2}{|c|}{$\mathbf{9 . 4 1}$} & & $\mathbf{1 1 . 5 2}$ & \\
\hline S.Em. & \multicolumn{2}{|c|}{$\mathbf{3 . 3 6}$} & & $\mathbf{4 . 1 1}$ & \\
\hline
\end{tabular}

Table. 3 Individual effect of $\mathrm{F}$ and $\mathrm{T}$ on acidity per cent of frozen aonla

\begin{tabular}{|c|c|c|c|c|c|c|}
\hline Treatments & $\mathbf{1}$ & $\mathbf{2}$ & $\mathbf{3}$ & CD at 5\% & S.Em. \pm & CV \% \\
\hline F & 1.528 & 1.457 & & $\mathbf{0 . 0 2 3}$ & $\mathbf{0 . 0 0 8}$ & \\
\hline T & 1.892 & 1.483 & 1.102 & $\mathbf{0 . 0 2 8}$ & $\mathbf{0 . 0 1 0}$ & $\mathbf{4 . 1 0 5}$ \\
\hline
\end{tabular}

Table.4 Interaction effects of $\mathrm{F} \times \mathrm{T}$ on acidity per cent of frozen aonla

\begin{tabular}{|c|c|c|}
\hline Treatments & $F_{1}$ & $\mathbf{F}_{2}$ \\
\hline T1 & 1.910 & 1.874 \\
\hline T2 & 1.540 & 1.427 \\
\hline T3 & 1.135 & 1.069 \\
\hline C.D at 5\% & \multicolumn{2}{|c|}{0.039} \\
\hline S.Em. \pm & \multicolumn{2}{|c|}{0.010} \\
\hline
\end{tabular}

Table.5 Individual effect of F, P and T on tannin content of frozen aonla

\begin{tabular}{|c|c|c|c|c|c|c|}
\hline Treatments & $\mathbf{1}$ & $\mathbf{2}$ & $\mathbf{3}$ & CD at 5\% & S.Em. \pm & CV \% \\
\hline F & 3.77 & 3.58 & & $\mathbf{0 . 0 2}$ & $\mathbf{0 . 0 0 8}$ & \multirow{2}{*}{$\mathbf{1 . 8 8}$} \\
\cline { 1 - 6 } P & 3.76 & 3.62 & 3.63 & $\mathbf{0 . 0 3}$ & $\mathbf{0 . 0 0 9}$ & \\
\hline T & 4.35 & 3.57 & 3.10 & $\mathbf{0 . 0 3}$ & $\mathbf{0 . 0 0 9}$ & \\
\hline
\end{tabular}

Table.6 Interaction effects of $\mathrm{F} \times \mathrm{T}$ and $\mathrm{P} \times \mathrm{T}$ on tannin content of frozen aonla

\begin{tabular}{|c|c|c|c|c|c|}
\hline Treatments & $F_{1}$ & $\mathbf{F}_{2}$ & $\mathbf{P}_{1}$ & $\mathbf{P}_{2}$ & $\mathbf{P}_{3}$ \\
\hline T1 & 4.36 & 4.35 & 4.40 & 4.33 & 4.34 \\
\hline T2 & 3.74 & 3.39 & 3.70 & 3.51 & 3.49 \\
\hline T3 & 3.21 & 2.99 & 3.19 & 3.04 & 3.08 \\
\hline CD at $5 \%$ & \multicolumn{2}{|c|}{0.04} & \multicolumn{3}{|c|}{0.05} \\
\hline S.Em. \pm & \multicolumn{2}{|c|}{0.01} & \multicolumn{3}{|c|}{0.02} \\
\hline
\end{tabular}


Table.7 Interaction effects of $\mathrm{F} \times \mathrm{T}$ on acidity per cent of frozen aonla

\begin{tabular}{|c|c|c|c|}
\hline Treatments & $\mathbf{T}_{\mathbf{1}}$ & $\mathbf{T}_{\mathbf{2}}$ & $\mathbf{T}_{\mathbf{3}}$ \\
\hline $\mathbf{F}_{\mathbf{1}} \mathbf{P}_{\mathbf{1}}$ & 4.41 & 3.89 & 3.26 \\
\hline $\mathbf{F}_{\mathbf{1}} \mathbf{P}_{\mathbf{2}}$ & 4.30 & 3.67 & 3.16 \\
\hline $\mathbf{F}_{\mathbf{1}} \mathbf{P}_{\mathbf{3}}$ & 4.35 & 3.66 & 3.20 \\
\hline $\mathbf{F}_{\mathbf{2}} \mathbf{P}_{\mathbf{1}}$ & 4.39 & 3.50 & 3.11 \\
\hline $\mathbf{F}_{\mathbf{2}} \mathbf{P}_{\mathbf{2}}$ & 4.35 & 3.35 & 2.91 \\
\hline $\mathbf{F}_{\mathbf{2}} \mathbf{P}_{\mathbf{3}}$ & 4.32 & 3.32 & 2.96 \\
\hline CD at 5\% & \multicolumn{3}{|l}{$\mathbf{0 . 0 6}$} \\
\hline S.Em.. & \multicolumn{3}{|l}{$\mathbf{0 . 0 2}$} \\
\hline
\end{tabular}

Table.8 Individual effect of F, P and T on TSS of frozen aonla

\begin{tabular}{|c|c|c|c|c|c|c|}
\hline Treatments & $\mathbf{1}$ & $\mathbf{2}$ & $\mathbf{3}$ & CD at 5\% & S.Em. & CV \% \\
\hline F & 12.42 & 12.49 & & $\mathbf{0 . 0 5}$ & $\mathbf{0 . 0 2}$ & \multirow{2}{*}{$\mathbf{1 . 3 6}$} \\
\cline { 1 - 6 } $\mathbf{P}$ & 12.65 & 12.38 & 12.33 & $\mathbf{0 . 0 7}$ & $\mathbf{0 . 0 2}$ & \\
\hline T & 12.10 & 12.55 & 12.71 & $\mathbf{0 . 0 7}$ & $\mathbf{0 . 0 2}$ & \\
\hline
\end{tabular}

Table.9 Individual effect of $\mathrm{F} \times \mathrm{T}$ and $\mathrm{P} \times \mathrm{T}$ on vitamin $\mathrm{C}$ content of frozen aonla

\begin{tabular}{|c|c|c|c|c|c|c|c|c|}
\hline Treatments & $F_{1}$ & $\mathbf{F}_{2}$ & $\mathrm{C}_{1}$ & $\mathrm{C}_{2}$ & $\mathrm{C}_{3}$ & $T_{1}$ & $\mathbf{T}_{2}$ & $T_{3}$ \\
\hline $\mathbf{P}_{1}$ & 12.60 & 12.70 & 12.60 & 12.70 & 12.66 & 12.13 & 12.81 & 13.01 \\
\hline$\overline{\mathbf{P}_{2}}$ & 12.31 & 12.45 & 12.46 & 12.36 & 12.31 & 12.11 & 12.36 & 12.66 \\
\hline $\mathbf{P}_{3}$ & 12.35 & 12.31 & 12.41 & 12.31 & 12.26 & 12.04 & 12.48 & 12.47 \\
\hline CD at 5\% & \multicolumn{2}{|c|}{$\begin{array}{l}.09 \\
\end{array}$} & \multicolumn{3}{|c|}{0.11} & \multicolumn{3}{|c|}{0.11} \\
\hline S.Em. \pm & \multicolumn{2}{|c|}{0.03} & \multicolumn{3}{|c|}{0.04} & \multicolumn{3}{|c|}{0.04} \\
\hline
\end{tabular}

Table.10 Individual effects of F, P and T on moisture per cent of frozen aonla

\begin{tabular}{|c|c|c|c|c|c|c|}
\hline Treatments & $\mathbf{1}$ & $\mathbf{2}$ & $\mathbf{3}$ & CD at 5\% & S.Em. \pm & CV \% \\
\cline { 1 - 6 } F & 80.68 & 79.35 & & $\mathbf{0 . 3 1}$ & $\mathbf{0 . 1 1}$ & \multirow{2}{*}{$\mathbf{1 . 2 4}$} \\
\cline { 1 - 6 } $\mathbf{P}$ & 80.30 & 79.85 & 79.90 & $\mathbf{0 . 3 8}$ & $\mathbf{0 . 1 4}$ & \\
\hline
\end{tabular}

Table.11 Interaction effect of $\mathrm{F} \times \mathrm{T}$ on moisture per cent of frozen aonla

\begin{tabular}{|c|c|c|}
\hline Treatments & $\mathbf{F}_{\mathbf{1}}$ & $\mathbf{F}_{\mathbf{2}}$ \\
\hline $\mathbf{T}_{\mathbf{1}}$ & 83.09 & 82.99 \\
\hline $\mathbf{T}_{\mathbf{2}}$ & 79.75 & 78.09 \\
\hline $\mathbf{T}_{\mathbf{3}}$ & 79.19 & 76.98 \\
\hline CD at 5\% & \multicolumn{3}{|c|}{$\mathbf{0 . 5 4}$} \\
\hline S.Em.. & \multicolumn{3}{|c|}{$\mathbf{0 . 1 9}$} \\
\hline
\end{tabular}


Table.12 Individual effects of F, P and T on firmness of frozen aonla

\begin{tabular}{|c|c|c|c|c|c|c|}
\hline Treatments & 1 & 2 & 3 & CD at $5 \%$ & S.Em. \pm & CV \% \\
\hline $\mathbf{F}$ & 6.23 & 6.43 & & 0.06 & 0.02 & \multirow{3}{*}{3.07} \\
\hline $\mathbf{P}$ & 6.60 & 6.20 & 6.20 & 0.07 & 0.03 & \\
\hline $\mathbf{T}$ & 10.12 & 4.45 & 4.43 & 0.07 & 0.03 & \\
\hline
\end{tabular}

Table.13 Interaction effects of $\mathrm{F} \times \mathrm{T}$ and $\mathrm{P} \times \mathrm{T}$ on firmness of frozen aonla

\begin{tabular}{|c|c|c|c|c|c|}
\hline Treatments & $\mathbf{F}_{1}$ & $\mathbf{F}_{2}$ & $\mathbf{P}_{1}$ & $\mathbf{P}_{2}$ & $\mathbf{P}_{3}$ \\
\hline$T_{1}$ & 10.14 & 10.10 & 10.13 & 10.10 & 10.12 \\
\hline $\mathbf{T}_{2}$ & 4.32 & 4.59 & 4.10 & 4.29 & 4.26 \\
\hline $\mathbf{T}_{3}$ & 4.24 & 4.61 & 4.10 & 4.20 & 4.21 \\
\hline CD at $5 \%$ & \multicolumn{2}{|c|}{0.54} & \multicolumn{3}{|c|}{0.13} \\
\hline S.Em. \pm & \multicolumn{2}{|c|}{0.04} & \multicolumn{3}{|c|}{0.05} \\
\hline
\end{tabular}

\section{Total Soluble Solids (TSS \%)}

Significant changes in TSS of aonla fruits were observed among different treatments (Table 8). In fruit preparation type, sliced fruits $\left(\mathrm{F}_{2}\right)$ recorded significantly higher TSS content than whole fruits $\left(\mathrm{F}_{1}\right)$. The higher TSS content may be accounted to increased concentration of the juice in aonla slices due to loss of moisture during slicing process (Jawanda et al., 1978). The results are in conformity with those of Singh et al., (1987) and Patra and Sadhu (1992). Aonla fruits packed in $\mathrm{P}_{1}$ (aluminum foil bag) recorded significantly higher TSS than $\mathrm{P}_{2}$ and $\mathrm{P}_{3}$ which might be due to slow physiological changes during storage. After eight month of storage the aonla fruits had significantly higher TSS content than $T_{1}$ (initial) and $T_{2}$ (after four month of storage) mainly due to increased concentration of juice as a result of dehydration during storage.

The interactions of $\mathrm{F} \times \mathrm{P}, \mathrm{C} \times \mathrm{P}$, and $\mathrm{T} \times \mathrm{P}$ were found to have significant effect on TSS of aonla (Table 9). In $\mathrm{F} \times \mathrm{P}$ interactions, the treatment combination of $\mathrm{F}_{2} \mathrm{P}_{1}$ (slices packed in aluminium foil bag) had significantly highest TSS than the rest. The aonla slices had less moisture hence higher concentration of the juice as compared to whole fruits. On the other hand, aluminium foil packaging slowed down the physiological changes. In case of $\mathrm{C} \times \mathrm{P}$ interactions, the treatment combination of $\mathrm{P}_{1} \mathrm{C}_{2}$ had maximum TSS which was at par with $\mathrm{P}_{1} \mathrm{C}_{1}$ and $\mathrm{P}_{1} \mathrm{C}_{3}$.From $\mathrm{P} \times \mathrm{T}$ interactions, the fruits packed in aluminium foil bag for eight months $\left(\mathrm{P}_{1} \mathrm{~T}_{3}\right)$ recorded significantly highest TSS which mainly due to effect of prolonged storage that increased the concentration of juice as a result of dehydration.

\section{Moisture (\%)}

There were significant differences for moisture content of aonla due to different treatments (Table 10). Whole fruits recorded significantly higher moisture as compared to slices of fruits which is obvious as slices loss moisture during slicing process in the form of juice and evapo-transpiration from cut surface. Similarly, fruits at initial level contained significantly the highest moisture as compared to four and eight months of storage. From the packaging treatments, aonla fruits packed in aluminum foil bag $\left(\mathrm{P}_{1}\right)$ had significantly the highest moisture content than fruits packed in polyethylene bag and laminated paper box. This might be due to 
lower rate of respiration and transpiration in aluminum foil bag.

The $\mathrm{F} \times \mathrm{P}$ interactions had significant effect on moisture content of fresh and frozen aonla (Table 11$)$. Fresh fruits $\left(F_{1} T_{1}\right)$ had maximum moisture followed by fruit slices at initial period. The results also showed that with increasing storage period, moisture content of aonla decreased significantly in both the type of fruit preparation but moisture loss was less in fresh fruits as compared to slices which is due to more evapo-transpiration from cut surface.

\section{Firmness $\left(\mathrm{kg} / \mathrm{cm}^{2}\right)$}

The individual effects of treatments were significant for the firmness of frozen aonla (Table 12). Fruit slices were found significantly more firm than whole fruits in frozen situation. This might be due to the fact that fruit slices required less time to freeze as compared to whole fruits. Quick freezing resulted in formation of fine ice crystals which caused less injury to the cell structure and helped in better maintenance of texture including firmness of aonla slices. On the other hand, slow freezing resulted in formation of coarse ice crystals that caused more injury tothe cell structure of whole fruits (Purthi, 1994).

In case of packaging, aonla fruits packed in aluminium foil bag had significantly higher firmness as compared to polyethylene bag and laminated paper box. This may be due to decreased physico-chemical changes by controlling the respiration as well as protection of cell structure from freezing injury.From storage periods, fresh aonla fruits $\left(\mathrm{T}_{1}\right)$ had significantly higher firmness which reduced significantly during storage for four and eight months in frozen condition. In frozen condition, the liquids solidify inform of ice crystals and lacerate the tissues which decreased the firmness of fruits during storage.

Interaction effects of $\mathrm{F} \times \mathrm{T}$ and $\mathrm{P} \times \mathrm{T}$ were found effective for firmness of frozen aonla (Table 13). In case of FxT interactions, the $\mathrm{F}_{1} \mathrm{~T}_{1}$ treatment combination i.e. fresh whole fruits have significantly the highest firmness than any other treatment combinations except $F_{2} T_{1}$ i.e. fresh fruit slices which is obvious. After four and eight months of storage the firmness of the fruits (whole and sliced) reduced mainly due to injury in cell structure. Among the $\mathrm{P} \times \mathrm{T}$ interactions, the fresh fruits packed in aluminium foil bag $\left(\mathrm{P}_{1} \mathrm{~T}_{1}\right)$ had maximum firmness and it remained at par with $\mathrm{P}_{2} \mathrm{~T}_{1}$ and $\mathrm{P}_{3} \mathrm{~T}_{1}$. This is only because of fresh condition of fruits. At later stage of storage the firmness of frozen aonla was reduced significantly, but the rate of reduction was significantly less in $\mathrm{P}_{1}$ packing as compared to $\mathrm{P}_{2}$ and $\mathrm{P}_{3}$ packing materials. This may be due to packaging in aluminium foil bag provided better protection to cell structure from freezing injuries.

\section{References}

Bhullar, J. S., Khokhar, U. U and Agnihotri, R. P. 1981. Storage behaviour of 'Kinnow' mandarin. Punjab Hort. J., 21(1\& 2): 27-31.

Jawanda, J. S., Singh, R. and Vij, V. K. 1978. Studies on extending post-harvest life of 'Kinnow' mandarin. Punjab Hort. J., 18 (3 \& 4): 149-153.

Mapson, L. W., 1970. Vitamins in fruit. Stability of L-ascorbic acid. (In) Biochemistry of fruits and their products, Vol. 1, chaptor XXI, pp. 376377.Hulme. A. C. (Ed). Academic Press, London.

Nath, V., Singh, I. S., Sanjeev Kumar and Pandey, A. K. 1992. Effect of postharvest treatments on shelf life of aonla fruits. Prog. Hort., 24 (1-2): 
79-82.

Patra, D. K., and Sadhu, M. K. 1992. Influence of post-harvest calcium treatment on shelf life and quality of litchi fruits. South Indian Hort., 40 (5): 252-256.

Purthi, J.F., 1994. Quick frozen food industryA global overview. Indian food packer, 48(3): 47-62.

Ranganna, S., 1979. "Manual of analysis of fruits and vegetable products". Tata McGraw Hill Publishing Co. Ltd., New Delhi.

Schanderl, S. H., 1970. In: Method in Food
Analysis. Academic Press, New York. p.709.

Singh, R. N., Singh, G., Mishra, J. S. and Rao, O. P. 1987. Studies on the effect of pre and post-harvest treatment of calcium nitrate and calcium chloride on the storage life of 'Amrapali' mango. Progressive Hort., 19 (1-2): 1-9.

Thakur, B. R., and Arya, S. S. 1988. Relative suitability of plastic films for the frozen storage of mango pulp.J. Food Processing and preservation, 12(3): 171-178.

\section{How to cite this article:}

Patel, V.K., B.H. Panchal, M.C. Joshi and Khimani, R.A. 2017. Changes in Bio-Chemical Properties of Whole and Sliced Fruits of Frozen Aonla cv. "Gujarat Aonla-1" Treated with Anti Darkening Chemical and Different Packaging. Int.J.Curr.Microbiol.App.Sci. 6(10): 335-342. doi: https://doi.org/10.20546/ijcmas.2017.610.041 